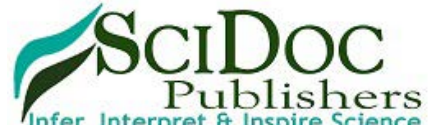

\author{
International Journal of Dentistry and Oral Science (IJDOS) \\ ISSN: 2377-8075
}

\title{
Effectiveness of Ultrasonic Activation of Endosequense BC Sealer and the Type of Gutta-Percha Pointon the Root Canal Filling Quality (An In-Vitro Study)
}

Research Article

\author{
Adnan alafandi ${ }^{1}$, Samar Akil ${ }^{2}$, Haya Ajalyakeen ${ }^{3}$, Abdulmalek Adi ${ }^{4}$, Muaaz Alkhouli ${ }^{*}$ \\ ${ }^{1}$ Department of Endodontics, Faculty of Dentistry, Damascus University, Syria. \\ ${ }^{2}$ Professor at Department of Endodontics, Faculty of Dentistry, Damascus University, Syria. \\ ${ }^{3}$ Department of oral Histology and Pathology, Faculty of Dentistry, Damascus University, Syria. \\ ${ }^{4}$ Department of Pediatric Dentistry, Faculty of Dentistry, Damascus University, Syria. \\ ${ }^{5}$ Department of Pediatric Dentistry, Faculty of Dentistry, Damascus University, Syria
}

\section{Abstract}

\begin{abstract}
Objectives: This study aims to evaluate the effectiveness of ultrasonic activation and $\mathrm{BC}$ gutta-percha points in the obturation of root canals.

Materials and Methods: The study sample consisted of 40 single rooted lower premolars extracted for orthodontic reasons. Root canal treatment was done after decoronation and equalization the length of the roots. The sample was divided randomly into four groups $(\mathrm{n}=10)$ depending on whether or not ultrasonic activation used and the type of gutta-perhapoints: group 1: ultrasonic activation used for EndoSequence BC sealer are used with traditional gutta-percha (UAGP), group 2: ultrasonic activation used for EndoSequence BC sealer are used with BC gutta-percha (UABC), group 3: ultrasonic activation was not used for BC sealer with traditional gutta-percha (NAGP). group 4: ultrasonic activation was not used with BC gutta-percha (NABC). After filling the teeth, a microleakage test with $2 \%$ methylene blue was performed for all samples. Then, all samples were studied on a $20 \mathrm{X}$ stereomicroscope after clearing them. The data was subjected to statistical analysis using one-way ANOVA Test with a $\mathrm{p}$ value $(\mathrm{p}<0.05)$ and the confidence level $(95 \%)$.

Results: There were statistically significant differences in the average amount of microleakage $(\mathrm{mm})$ between the filling groups with ultrasonic activation and the non-activation groups. While using endosequence BC points showed no significant differences. Conclusion: Ultrasonic activation of EndoSequence BC sealer improves root filling quality and reduces microleakege percentage. While using endosequence $\mathrm{BC}$ points showed no reduction in the microleakage level.
\end{abstract}

Keywords: Ultrasonic Activation; Root Filling Quality; Endosequence BC Sealer; Endosequence BC Points.

\section{Introduction}

The success of root canal treatment mainly depends on the three dimensional obturation of the root canal system, which prevents bacteria from penetrating into periapical tissues [1]. Bioceramic sealers have been introduced recently due to their characteristics, they are biocompatible, nontoxic, have no shrinking, and chemically stable within the biological environment [2]. BC sealers are set to use with cold obturation technique, such as Single coneobturation technique. Although BC sealers with single cone have shown good results, they have many disadvantages such as voids, gaps formation and bad adaptation with root canal walls [3].
Ultrasonic activation is used to enhance irrigants cleaning [4]. It is introduced recently to improve root filling quality [5]. Endosequence BC Points (Brasseler USA) are a new guttapercha impregnated and coated with $\mathrm{BC}$ nanoparticles [6]. According to the manufacturer, the bioceramic particles in EndoSequence Sealer attach to the bioceramic particles in the $\mathrm{BC}$ sealer to modulate a gap-free filling.

In this research, we studied the effect of ultrasonic activation andthe advantages of using Endosequence BC points on the apical microleakage.

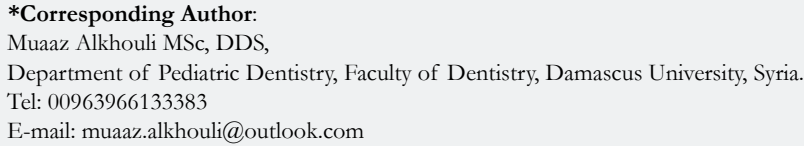

Received: November 14, 2020

Citation: Adnan alafandi, Samar Akil, Haya Ajalyakeen, Abdulmalek Adi, Muaaz Alkhouli. Effectiveness of Ultrasonic Activation of Endosequense BC Sealer and the Type of Gutta-Percha Pointon the Root Canal Filling Quality (An In-Vitro Study). Int J Dentistry Oral Sci. 2020;7(12):1160-1163. doi: http://dx.doi.org/10.19070/2377-8075-20000230

Copyright: Muaaz Alkhouli 2020 . This is an open-access article distributed under the terms of the Creative Commons Attribution License, which permits unrestricted use, distribution and reproduction in any medium, provided the original author and source are credited. 


\section{Materials and Methods}

\section{Study samples}

The study sample consisted of 40 single rooted lower premolars extracted for orthodontic reasons, with fully formed apices.

The sample was divided randomly into four groups $(\mathrm{n}=10)$ depending on whether or not ultrasonic activation used and the type of gutta-percha points.

Group 1: ultrasonic activation used for Endosequence BC sealer with traditional gutta-percha points (Sure-endo; Korea) (UAGP)

Group 2: ultrasonic activation used for Endosequence BC sealer with Endosequence BC gutta-percha points (Brasseler; USA) (UABC)

Group 3: Endosequence BC sealer with traditional gutta-percha (NAGP) without ultrasonic activation.

Group 4: Endosequence BC sealer with BC gutta-percha (NABC) without ultrasonic activation.

\section{Laboratory Procedure}

Roots were cleaned and stored in distilled water. Crowns were decoronated using a thin diamond bur (FG 167, HoricoDental; Germany) to achieve standard length of $15 \mathrm{~mm}$. The working length was established by subtracting $0.5 \mathrm{~mm}$ from the length. Root canal shaping were performed with SC2 (size 25, taper 0.4) RevoS Niti rotary instrument (MicroMega; France). Root canals were irrigated with $1 \mathrm{ml} 5.25 \% \mathrm{NaOCl}$ between instruments changes. A final irrigationwas applied using $5 \mathrm{ml} \mathrm{5.25 \% \textrm {NaOCl }}$ for $1 \mathrm{~min}$ and $5 \mathrm{ml}$ EDTA solution (MetaBiomed, Korea) for another $1 \mathrm{~min}$ and then $3 \mathrm{ml}$ of distilled water as a final rinse.

Endosequence BC sealer (Brassler; USA) is a premixed tube form. Sealer was injected into the coronal one third of the canals using the tip of the syringe. Then, the sealer was inserted into the canals using $25 \mathrm{k}$-file (Mani, Japan), $1 \mathrm{~mm}$ shorter than the working length. This was done for the all four groups.

After that, ultrasonic activation of the sealer was performed for 20 seconds $2 \mathrm{~mm}$ short of the working length in the first and second groups. Ultrasonic activation was performed using $0.2 \mathrm{ul}$ trasonic tip (Ultra x eighteeth; Changzhou) at power level of 2 (45 KHZ).
The Master cone of both types of gutta-percha (25/04) wascoated with a thin layer of the sealer and inserted slowly into canals for all the groups in the same way.

After radiographic confirmation of complete filling of canals, excess gutta-percha was removed with heated instrument. Then coronal orifices were sealed with GIC (Fuji plus) restorative material. All the specimens were then stored in a humidifier with $100 \%$ humidity and temperature maintained at $37^{\circ} \mathrm{C}$ for 1 week. After that, samples were dried and coated with nail varnish (leaving a margin of $1 \mathrm{~mm}$ from the apex).

\section{Outcomes measurement}

A Dye Penetration test with $2 \%$ methylene blue was performed for all samples for 24 hours. After that, samples were washed with water for 15 minutes. Samples were decalcified with nitric acid for 3 days, and dehydrated with alcohol for 16 hours, and cleared with methyl salicylate for 4 hours (figure 1).

All samples were studied on a $20 \mathrm{X}$ stereomicroscope by two blinded investigators.

\section{Statistical analysis}

Data were subjected to statistical analysis using one-way ANOVA Test with a $\mathrm{P}$ value $(\mathrm{p}<0.05)$ and the confidence level $(95 \%)$. Moreover,we used Bonferroni test for multiple comparisons between the study groups.

\section{Results}

There was a significant difference between the microleakage of the apical third of the groups $(\mathrm{P}=0.000)$. The use of ultrasonic activation with Endosequence BC sealer resulted in lower apical microleakage than with no activation $(\mathrm{P}<0.05)$. While using Endosequence $\mathrm{BC}$ points showed no significant differences.

one-way ANOVA Test (table 2) was conducted and showed positive differentiation rates between at least two groups with P-value less than 0.05. and for further investigation boneferroni test (table 3) was conducted afterwards to make multiple comparisons between the groups. The results showed positive differentiation between ultrasonic activation and non-activation groups. While no significant differentiation was found between endosequence $\mathrm{BC}$ gutta-percha and the traditional gutta-percha.

Figure 1. Dye penetration test shows less microleakage in ultrasonic activation sample (left) than sample without activation (right).

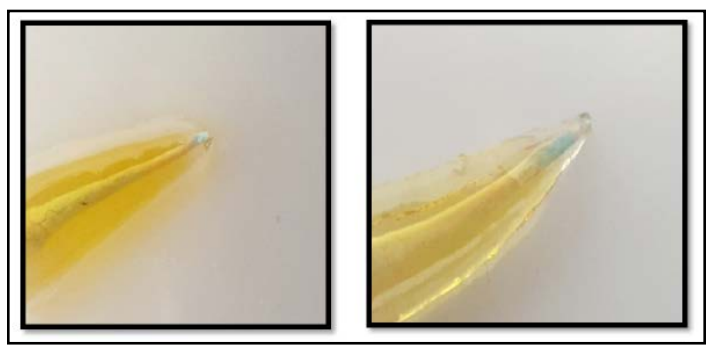


Table 1. Mean, standard deviation and standard error for microleakage of the apical third of the groups.

\begin{tabular}{|c|c|c|c|c|}
\hline \multicolumn{5}{|c|}{ the studied variant: apical microleakage (in ml) } \\
\hline $\begin{array}{c}\text { OPTURATION } \\
\text { METHOD }\end{array}$ & $\begin{array}{c}\text { SAMPLE } \\
\text { NUMBER }\end{array}$ & MEAN & $\begin{array}{c}\text { STANDARD } \\
\text { DEVIATION }\end{array}$ & $\begin{array}{c}\text { STANDARD } \\
\text { ERROR }\end{array}$ \\
\hline UAGP & 10 & 0.82 & 0.19 & 0.06 \\
\hline UABC & 10 & 0.80 & 0.19 & 0.06 \\
\hline NAGP & 10 & 1.43 & 0.16 & 0.05 \\
\hline NABC & 10 & 1.39 & 0.20 & 0.06 \\
\hline
\end{tabular}

Table 2. One-way ANOVA test to show microleakage differentiation between all groups.

\begin{tabular}{|c|c|c|c|}
\hline $\begin{array}{c}\text { THE STUDIED } \\
\text { VARIANT }\end{array}$ & F VALUE & P VALUE & DIFFERENTIATION \\
\hline $\begin{array}{c}\text { Apical Microleakage } \\
\text { (in ML) }\end{array}$ & 34.218 & 0 & SIGNIFICANT DIFFERENCES \\
\hline
\end{tabular}

Table 3. Bonferroni test to show multiple comparisons between the study groups.

\begin{tabular}{|c|c|c|c|c|c|}
\hline \multicolumn{6}{|c|}{ The Studied Variant: Apical Microleakage (in ML) } \\
\hline & & $\begin{array}{c}\text { Difference } \\
\text { between means }\end{array}$ & $\begin{array}{c}\text { Standard error } \\
\text { between }\end{array}$ & P Value & Differentiation \\
\hline UABC & NABC & -0.59 & 0.08 & 0.000 & S \\
\hline & UAGP & -0.02 & 0.08 & 1.000 & NS \\
\hline & NAGP & -0.63 & 0.08 & 0.000 & S \\
\hline NABC & UAGP & 0.57 & 0.08 & 0.000 & S \\
\hline & NAGP & -0.04 & 0.08 & 1.000 & NS \\
\hline UABC & NAGP & -0.61 & 0.08 & 0.000 & S \\
\hline
\end{tabular}

*S: significant differences, NS: no significant differences.

\section{Discussion}

This study was conducted on extracted lower premolers with a single root, single rounded canal, free of internal or external absorbtion in order to obtain a good canal obturation [7]. The same preparation technique was used in all canals with repeated irrigation with $5.25 \% \mathrm{NaOCl}$, and with $17 \%$ EDTA solution to remove the smear layer which make a better sealer penetration in the dentinal tubules [8]. A single paper point cone was used to dry each canal in order to make a better sealing between $\mathrm{BC}$ sealer and canals walls [9].

Single cone oburation technique has been introduced to reduce working time and obturation mistakes (10), as well as sealer quantity in the filling material. Even though, it showed higher number of voids and gaps in the filling material (11); which has led to suggest the use of ultrasonic activation of the sealer during root canal obturtion(12)(13).In this study, ultrasonic activation did not show higher exceed of sealer material over the apex; this can be ascribed to the distance $(2 \mathrm{~mm})$ between the ultrasonic tip and the apex, beside the low frequency of ultrasonic activation device (14).

Apical third of the canal is the most important third because it has more lateral canals than the other two thirds, and these lateral canalsare connected with periapical tissues. However, they are a home for bacteria which derive from pulpal or periapical tissues [15]. Those bacteria are the direct reason for periapical lesions.

Dye Penetration Technique is one of the most commonmethods which are used to evaluate root filling quality and sealer sealability. This technique is simple, cheap and do notneed any complicatedequipment [16].

Cohen's kappa test was used to calculate intra-examiner reproducibility and inter-examiner reliability for the assessment of test variables. The kappa for intra-examiner agreement and inter-examiner reliability was 0.90 .

Results showed that samples with ultrasonic activation had a lower apical microleakage which can refer to the increase in tubular penetration for the ultrasonic activation groups [13]. Ultrasonic activation also reduces the number of voids and gaps [17] and can result in better filling for the lateral canals [12].

Arslan in 2016, has found better peneteration of sealer into lateral canals with the ultrasonic activation use compared to sonic activation and non-activation groups [5].

Wiesse et al., [14] studied the effect of ultrasonic activation of root canal sealer on the push-out bond strength and interfacial adaptation to root canal dentine. Those studies are in agreement with our results, as they conclude that ultrasonic activation re- 
sulted in higher bond strength and better interfacial adaptation of sealers to canal walls.

The type of gutta-percha cone did not make a significant difference in microleakage between the groups. These findings may refer to incapability of the nano-particles in Endosequence BC points to make better bonding with sealer or canal walls. The mentioned result can be attributed to the method used in this study, whichexamined the microleakage between sealer and canal walls and the less between sealer and cone material.

Yanpiset et al, examined the bacterial leakage around BC guttapercha points with $\mathrm{BC}$ sealer compared to traditional gutta-percha with $\mathrm{BC}$ sealer using single cone obturation technique. Results of this study agreed with our study as they obtained a comparable scores among the two gutta-percha types [18].

Al Haddad in 2018 [19] compared the apical sealing of BC point with traditional one by applying push-out test on their specimens and showed resembling results between the two types. These findings are also in the line with the present study in spite of the different testing method.

Limitation of our study is the small sample size.

\section{Conclusions}

Under the conditions of this study, the use of ultrasonic activation of EndoSequence BC sealer improves root filling quality and reduces microleakege percentage. While using endosequence $\mathrm{BC}$ points showed no reduction in the microleakage level.

\section{References}

[1]. Naseri M, Kangarlou A, Khavid A, Goodini M. Evaluation of the quality of four root canal obturation techniques using micro-computed tomography. Iran Endod J. 2013;8(3):89.PubmedPMID: 23922567.

[2]. Loushine BA, Bryan TE, Looney SW, Gillen BM, Loushine RJ, Weller RN, et al. Setting properties and cytotoxicity evaluation of a premixed bioceramic root canal sealer. J Endod. 2011;37(5):673-7. Pubmed PMID: 21496669.

[3]. Whitworth J. Methods of filling root canals: principles and practices. Endod Top. 2005;12(1):2-24. =

[4]. Galler KM, Grubmüller V, Schlichting R, Widbiller M, Eidt A, Schuller C, et al. Penetration depth of irrigants into root dentine after sonic, ultrasonic and photoacoustic activation. Int Endod J. 2019;52(8):1210-7. Pubmed
PMID: 30828819.

[5]. Arslan H, Abbas A, Karatas E. Influence of ultrasonic and sonic activation of epoxy-amine resin-based sealer on penetration of sealer into lateral canals. Clin Oral Investig. 2016;20(8):2161-4. Pubmed PMID: 26818582.

[6]. Gervini MJ, Pacheco-Yanes J, Gonçalves LS, Lopes HP, Vieira VTL, Siqueira Jr JF, et al. Fracture resistance of roots filled with either a bioceramic or an epoxy resin-based sealer. ENDO-ENDODONTIC Pract TODAY. 2018;12(2):119-23.

[7]. Nilsson E, Bonte E, Bayet F, Lasfargues J-J. Management of internal root resorption on permanent teeth. Int J Dent. 2013;2013. Pubmed PMID: 24348560.

[8]. Vemuri S, Kolanu SK, Varri S, Pabbati RK, Penumaka R, Bolla N. Effect of different final irrigating solutions on smear layer removal in apical third of root canal: A scanning electron microscope study. J Conserv Dent JCD. 2016;19(1):87. Pubmed PMID: 26957801.

[9]. Taşdemir T, Er K, Çelik D, Tahan E, Serper A, Ceyhanli KT, et al. Bond strength of calcium silicate-based sealers to dentine dried with different techniques. Med Princ Pract. 2014;23(4):373-6.Pubmed PMID: 24903084.

[10]. Pereira AC, Nishiyama CK, de Castro Pinto L. Single-cone obturation technique: a literature review. RSBO Rev Sul-Brasileira Odontol. 2012;9(4):442-7.

[11]. Taşdemir T, Er K, Yildirim T, Buruk K, Çelik D, Cora S, et al. Comparison of the sealing ability of three filling techniques in canals shaped with two different rotary systems: a bacterial leakage study. Oral Surgery, Oral Med Oral Pathol Oral Radiol Endodontology. 2009;108(3):e129-34.Pubmed PMID: 19716483.

[12]. Sungur DD, Moinzadeh A-T, Wesselink PR, Tarhan SÇ, Özok AR. Sealing efficacy of a single-cone root filling after post space preparation. Clin Oral Investig. 2016;20(5):1071-7. Pubmed PMID: 26411973.

[13]. Chadgal S, Farooq R, Purra AR, Ahangar FA, Amin K, Lone OH. Ultrasonic activation of a bioceramic sealer and its dentinal tubule penetration: An in vitro study. Ann Int Med Dent Res. 2018;4(2):51-4.

[14]. Wiesse PEB, Silva-Sousa YT, Pereira RD, Estrela C, Domingues LM, Pécora JD, et al. Effect of ultrasonic and sonic activation of root canal sealers on the push-out bond strength and interfacial adaptation to root canal dentine. Int Endod J. 2018;51(1):102-11. Pubmed PMID: 28543092.

[15]. Solomon C, Chalfin H, Kellert M, Weseley P. The endodontic-periodontal lesion: a rational approach to treatment. J Am Dent Assoc. 1995;126(4):4739. Pubmed PMID: 7722108

[16]. AI-Ghamdi A, Wennberg A. Testing of sealing ability of endodontic filling materials. Dent Traumatol. 1994;10(6):249-55.Pubmed PMID: 7867611.

[17]. Kim JA, Hwang YC, Rosa V, Yu MK, Lee KW, Min KS. Root Canal Filling Quality of a Premixed Calcium Silicate Endodontic Sealer Applied Using Gutta-percha Cone-mediated Ultrasonic Activation. J Endod [Internet]. 2018;44(1):133-8. Pubmed PMID: 29102078.

[18]. Yanpiset K, Banomyong D, Chotvorrarak K, Srisatjaluk RL. Bacterial leakage and micro-computed tomography evaluation in round-shaped canals obturated with bioceramic cone and sealer using matched single cone technique. Restor Dent Endod. 2018;43(3). Pubmed PMID: 30135849.

[19]. Al-Haddad AY, Kutty MG, Che Ab Aziz ZA. Al-Haddad, A. Y., Kutty, M G. en Che Ab Aziz, Z. A. (2018) "Push-out bond strength of experimental apatite calcium phosphate based coated gutta-percha”, International journal of biomaterials. Hindawi, 2018.Push-out bond strength of experimental apatite c. Int J Biomater. 2018;2018. 